\title{
PRIMARY SELECTION OF THE PREBIOTIC COMPONENTS IN THE COMPLEX DERMATOLOGICAL THERAPEUTIC AND PREVENTIVE MEDICINE WITH PROBIOTIC
}

\author{
A. Soloviova, O. Kaliuzhnaia, L. Strelnikov
}

\begin{abstract}
Мета. Вибір оптимальних пребіотичних компонентів для бактерій роду Lactobacillus з метою їх сумісного використання у складі м'якого комплексного дерматологічного лікувально-профілактичного засобу з пробіотиком.

Методи. Сумісне культивування пробіотичного штаму у рідкому живильному середовищі МРС із певним активним інгредієнтом у обраних концентраціях. Протягом ииклу культивування через певні проміжки часу відбирали зразки зростаючої культури для визначення концентрації бактерій методом прямого посіву і визначення кислотності.
\end{abstract}

Результати. Протягом 48 год сумісного культивування лактобактерій із обраними компонентами спостерігається суттєве збільшення життєздатних клітин, як в контролі, так і при додаванні вітамінів у обраних концентраціях (експоненціальна фаза росту бактерій), з 48 год до 60 год - зниження швидкості збільшення клітин як в контролі, так і в дослідах, кількість клітин залишається майже на постійному рівні (стаціонарна фаза росту бактерій), після 60 год - зменшення кількості клітин (фаза відмирання).

Протягом культивування відмічається закислення живильного середовища в результаті утворення з вуглеводів молочної кислоти та інших кінцевих метаболітів; тобто додання компонентів дещзо підвищує біохімічний потенціал мікроорганізмів, про цее свідчить нарощування біомаси та кислотного потенціалу. Незважаючи на відсутність суттєвої різниці між однією серією дослідів із різним вмістом вітамінів, найбільший приріст кількості життездатних клітин спостерігалось при вирощуванні із вітаміном В5 (серед обраних концентрацій при додаванні $1 \%$ ) та провітаміном В5 (при концентрації 2,5\%).

Висновки. Обрані пребіотичні компоненти оптимальні для використання разом із лактобактеріями у складі однієї лікарської форми, щчо розроблюється. Незважаючи на виражений синергізм дї для серій дослідів із вітаміном В5 та Д-пантенолом, всі інші компоненти є також перспективними через відсутність негативного впливу на лактобактерії та низку позитивних ефектів на шкіру людини

Ключові слова: лактобактерії, пробіотики, пребіотики, мікробіом шкіри, дерматологічні захворювання, лікувально-профілактичний засіб

Copyright (C) 2020, A. Soloviova, O. Kaliuzhnaia, L. Strelnikov. This is an open access article under the CC BY license (http://creativecommons.org/licenses/by/4.0).

\section{Introduction}

Skin has great importance in the life of the body, performs a number of vital functions, the main of them protective, which are carried out due to its biological properties. Protective functions due to the integrity of the skin, dense stratum corneum, exfoliation, acidic skin reaction, water-lipid membrane with $\mathrm{pH}-4,5-5,5$ (protection against microorganisms), the presence and structure of the stratum corneum of the epidermis, subcutaneous - fatty cell protection) and the glossy layer of the epidermis (protection against chemicals), etc. [1]. However, since the completion of Phase 1 of the Human Microbiome Project, it has become clear that each of us is a complex "mixture" of microorganisms and human cells [2]. In the skin, there are not only intercellular interactions, but also complex cooperations between cells and microorganisms that are on its surface, so the skin can be considered as a complex and multifunctional organ [3].

Many studies in microbiology, dermatology, and genetic studies have made it possible to describe in detail the composition of the skin microbiome. In 2009,
E. Grice and co-authors in the skin microbiome of a healthy adult identified 19 major groups of microorganisms with prevalent Actinobacteria (52\%), Firmicutes (24\%), Proteobacteria (17\%) and Bacteroidetes (7\%) [4]. Microorganisms such as Staphylococcus, Propionibacterium and Corynebacterium are most commonly detected, a lesser extent are present Micrococcus, Streptococcus, Brevibacterium, Acinetobacterium and Pseudomonas [5, 6]. The composition of the microbiome depends on the sex and age, features of climate and geographical location, nutrition, profession, lifestyle and, even, features of personal hygiene [7].

In addition, in 2013, R. Gallo, using modern metagenomic analysis techniques, not only confirmed the presence of certain groups of microorganisms on the skin surface, but also in the stratum of epidermis, under the basement membrane, and down to the fat stratum under the dermis [8].

Skin microflora plays an important role in maintaining homeostasis and local immunity, protecting against pathogenic bacteria, and developing an adaptive 
immune response. Disorders of the skin microbiome lead to the development of various dermatoses. Thus, information on the topographic diversity of the microbiome composition of different skin areas in normal and in pathology is used to determine the pathogenesis of acne, seborrheic dermatitis, rosacea (in the field of sebaceous glands), psoriasis (areas of dry skin), atopic dermatitis (skin areas with high humidity) [3]. In addition, many scientists have shown the dependence of the skin microbiome on the microenvironmental situation in other biotopes, especially in the intestinal [1].

In modern dermatology, skin diseases are defined not only as pathological processes in the skin, but more often as changes that occur in the internal organs, nervous system, metabolism, homeostasis, etc., which affect the skin [1]. In this regard, skin diseases should be prescribed with general treatment aimed at eliminating or correcting the etiopathogenetic factors of the disease, taking into account the need to restore or maintain the skin microbiome.

Non-specific active stimulating and adaptive stimulating immunotherapy agents are widely prescribed for the treatment of dermatoses [1]. And because of the clear relations between the microorganisms and the factors that cause the innate and adaptive immune response in the skin in normal and pathology, the use of probiotic bacteria, even which are not necessarily representatives of the skin microbiome, such as lactobacilli, which actively stimulate immunity, even with short-term contact with cells of the macroorganism, is promising in the treatment of dermatological diseases. Despite the fact that lactobacilli do not live on the skin, they cope well with "repair and restoration work" on the hydrolipid layer of the skin. Therefore, Lactobacillus plantarum probiotic applications in acne patients have reduced the number of inflammatory and noninflammatory elements [9].

In the treatment of patients with infectious dermatoses used antibiotics (penicillins, cephalosporins, macrolides, tetracyclines), which, in turn, further disrupt the natural microbiome of the skin [1]. Nevertheless, the presence of an antimicrobial component in complex therapy is desirable, and the high metabolic activity of lactobacilli with the formation of lactic acid, lysozyme, hydrogen peroxide, lactacin, short-chain fatty acids, histamines, etc., again, confirms the prospect of the use of lactobacilli [10]. Such studies should also take into account the $\mathrm{pH}$ values in norm and skin pathologies. The necessity of reducing the $\mathrm{pH}$ in acne from 7 to $4.5-5.5$ [1] causes the prospect of using lactobacilli, among their metabolites is lactic acid up to $70 \%$ [10].

In many skin diseases, vitamin therapy is prescribed, most often B vitamins: B1, B2, B5, B6, B12, vitamins $\mathrm{PP}, \mathrm{A}, \mathrm{E}, \mathrm{C}$, and the use of vitamins together with probiotic cultures is rational, because lactobacilli are very demanding for food sources and require for the development of various growth factors: aminoacids, vitamins, nucleotides [11].

The aim of the study was to select the most optimal prebiotic components, for bacteria of the genus Lactobacillus for their combined usage in the composition of a soft complex dermatological therapeutic and preventive medicine with a probiotic.

\section{Planning (methodology) of the research}

To achieve the aim it was necessary to solve the following problems:

- to analyse the properties, growth characteristics, cultivation conditions of production lactobacillus strains;

- to evaluate the potential prebiotic substances as components of a complex dermatological therapeutic and preventive medicine with a probiotic;

- to carry out a combined cultivation of production lactobacillus strains with selected components;

- to determine the effect of the selected components on the growth and metabolic activity of production lactobacillus strains.

\section{Materials and methods}

As a probiotic component for the study was selected standard for many human microbiome strain of bacteria of the genus Lactobacillus - non-pathogenic, non-toxic, gram-positive enzymatic microorganisms with the ability to produce lactic acid from carbohydrates and certain bactericidal and biologically active substances [12], that is the famous production strain of L. plantarum UCM - 2693, obtained from the collection of the D. K. Zabolotny Institute of Microbiology and Virology. As the active components were selected: vitamins of group $\mathrm{B}$, which, according to the literature, not only have a positive effect on the growth of lactic acid bacteria, showing synergism with probiotics, but also belong to the group of "skin" vitamins. They used as dermatoprotectants through their regenerating, anti-inflammatory, reparative action; D-panthenol - provitamin B5, known for its anti-inflammatory and healing properties; a complex of milk proteins (containing vitamin B6 and $\mathrm{H}$ and aminoacids), which normalizes the sebaceous glands, reduces the high level of skin fat, regulates the process of keratinization; $\alpha$-lipoic acid (thioctic acid, so-called "vitamin antioxidant"), which has antioxidant, protective and moderate anti-inflammatory action.

Analysing the existing topical preparations, the appropriate concentrations were selected starting from the lowest: pyridoxine hydrochloride, vitamin B6 - from 0.1 to $0.5 \%$; calcium D-pantothenate, vitamin B5 - from 1 to $5 \%$; D-panthenol, provitamin B5 - from 1 to $5 \%$; methylcobalamin, vitamin $\mathrm{B} 12$ - from 0.5 to $1 \%$; milk protein complex - from 1 to $5 \%$; $\alpha$-lipoic acid - from 2 to $5 \%$.

In order to use these components together in a dosage form, a co-cultivation of a probiotic strain was carried out in a liquid MRS nutrient medium with a certain active ingredient at the selected concentrations. The water-insoluble ingredient ( $\alpha$-lipoic acid) was emulsified with tween-80, which, in addition to its emulsifying properties, is a source of fatty acids necessary for the metabolism of lactobacilli [13] and has shown high survival rates for lactobacilli [14]. The seeding dose of the microorganisms was $1 \cdot 10^{8}$ colony forming units in $1 \mathrm{ml}$ $(\mathrm{CFU} / \mathrm{ml})$. The cultivation was carried out at a temperature of $37{ }^{\circ} \mathrm{C}$ under microaerophilic conditions for 72 hours.

Throughout the cultivation cycle, growing culture samples were taken at specific intervals to determine bacterial concentration by direct sowing and acidity determination. Control was an environment with pure cul- 
ture. According to the obtained data, graphs were constructed in natural and semi-logarithmic coordinates. If the number of cells of lactobacilli in the sample with the active ingredient was at the level with the control, it indicated the possibility of using this component in one dosage form, if higher than the control - the presence of synergism, if lower - inhibition of lactobacilli growth and their incompatibility in one dosage form.

\section{Research results}

As part of the complex dermatological therapeutic and preventive medicine which is being developed, it is planned to use the complex of known production strains of L. plantarum B-2693 and L. fermentum B-7052 for the full realization of the biological potential of lactobacilli. However, the rationality of the use of the method of separate cultivation in obtaining a complex probiotic has been proved [15], so the study of the possibility of using the selected ingredients was carried out on monocultures of production strains. This work presents the results of a study to determine the possibility of sharing selected prebiotic components with a strain of L. plantarum B2693.

The diagram in semi-logarithmic coordinates for L. plantarum with pyridoxine hydrochloride in concentration $0.1 \%, 0.25 \%, 0.5 \%$ is presented in Fig. 1 .

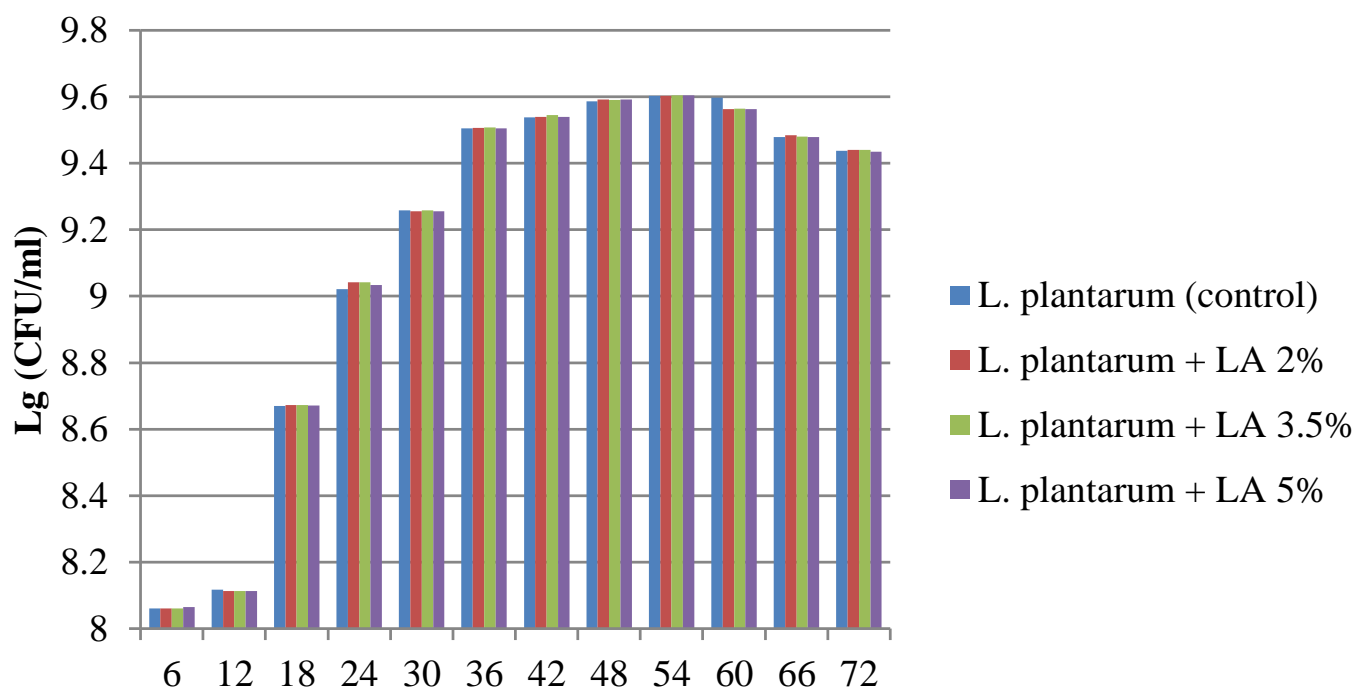

Cultivation time, hours

Fig. 1. Growth dynamics of L. plantarum B-2693 in co-cultivation with pyridoxine hydrochloride

During the first $48 \mathrm{~h}$ of cultivation, an exponential phase of bacterial growth was observed for each of the experiments. The number of viable lactobacilli cells was significantly increased, both in control and with the addition of vitamins at selected concentrations. Thus, for control of L. plantarum, cell number increase occurred from $(1.15 \pm 0.08) \cdot 10^{8} \mathrm{CFU} / \mathrm{ml}(\mathrm{Lg}-8.06)$ at $6 \mathrm{~h}$ of cultivation to $(3.86 \pm 0.24) \cdot 10^{9} \mathrm{CFU} / \mathrm{ml}(\mathrm{Lg}-9.59)$ at $48 \mathrm{~h}$ of cultivation. For example, in the case of $L$. plantarum $+0.5 \%$ B 6 at $6 \mathrm{~h}$ of cultivation, the number of viable cells was $(1.15 \pm 0,05) \cdot 10^{8} \mathrm{CFU} / \mathrm{ml}(\mathrm{Lg}-8.06)$, at $48 \mathrm{~h}-(3.87 \pm 0.21) \cdot 10^{9} \mathrm{CFU} / \mathrm{ml}(\mathrm{Lg}-9.59)$.

However, when comparing the results of the experiments with the addition of vitamin and in the control, it is possible to notice not a significant increase in the number of viable cells of lactobacilli, or no influence when adding vitamins at the selected concentrations. By $48 \mathrm{~h}$ of cultivation, the logarithm of the number of cells reached 9.59 , both for control of $L$. plantarum and with added $0.1 \%$ B6, $0.25 \%$ B6, $0.5 \%$ B6.
From $48 \mathrm{~h}$ to $60 \mathrm{~h}$ of cultivation there is a decrease in the rate of increase of viable cells both in control and with the addition of vitamins at selected concentrations, the number of cells remains almost constant. Thus, to control:

- at $54 \mathrm{~h}$ the number of cells was $(4.01 \pm 0.15) \cdot 10^{9} \mathrm{CFU} / \mathrm{ml}$,

- $\quad$ at $60 \mathrm{~h}-(3.95 \pm 0.05) \cdot 10^{9} \mathrm{CFU} / \mathrm{ml}$.

That is, a stationary phase of bacterial growth is observed, when the lack of nutritional components for growth because of glucose utilization and the use of other food components and growth factors, including vitamins at selected concentrations, becomes noticeable.

After $60 \mathrm{~h}$ of cultivation there is a decrease in the number of viable cells (logarithmic death phase). To control at $60 \mathrm{~h}$, the cell count is $(3.95 \pm 0.05) \cdot 10^{9} \mathrm{CFU} / \mathrm{ml}$, which is reduced to $(2.74 \pm 0.15) \cdot 10^{9} \mathrm{CFU} / \mathrm{ml}$ to $72 \mathrm{~h}$.

The results of the next series of experiments with the addition of calcium pantothenate in concentrations of $1 \%, 2.5 \%, 5 \%$ are shown in Fig. 2. 


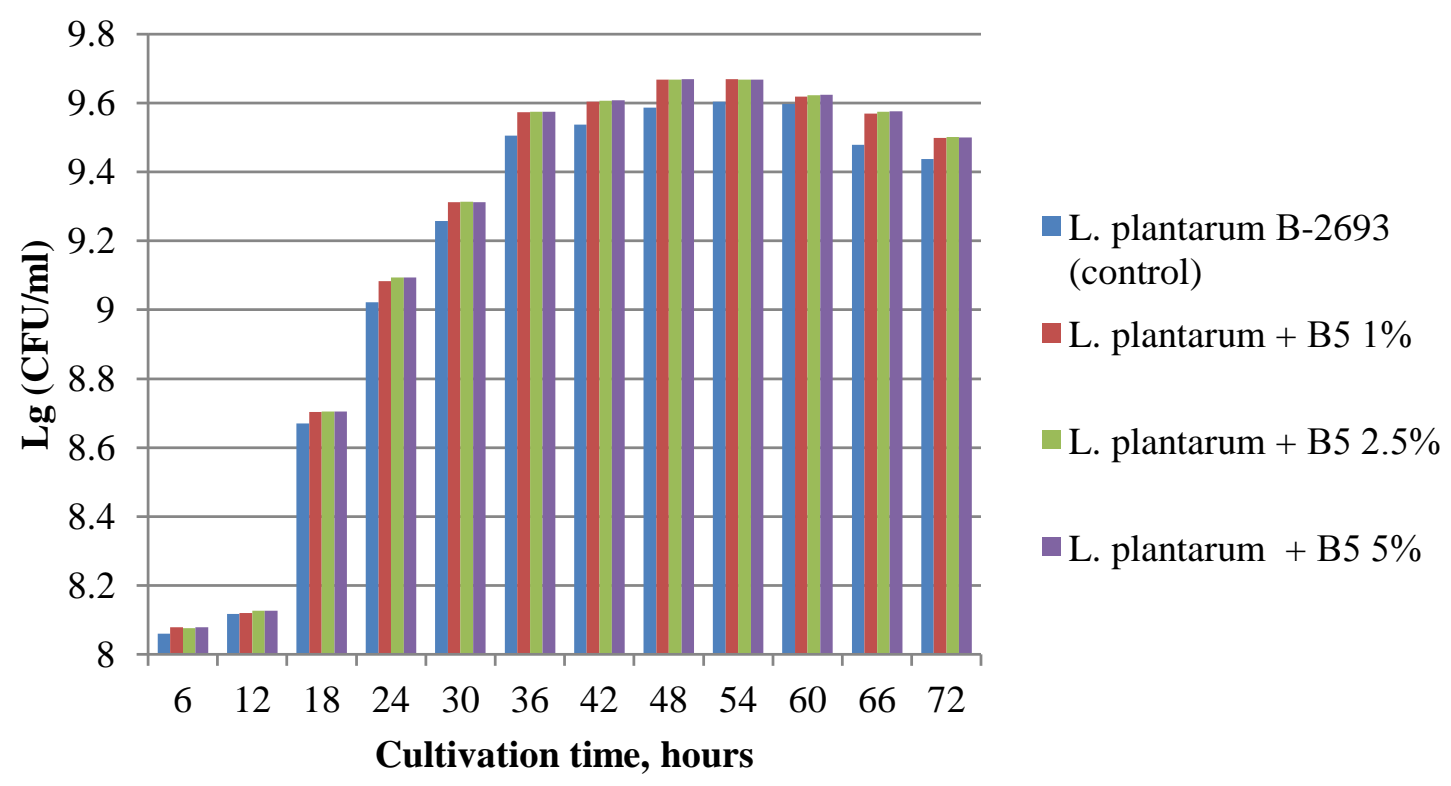

Fig. 2. Dynamics of growth of L. plantarum B-2693 in co-cultivation with calcium pantothenate

In accordance with Fig. 2, the general tendency of growth of lactobacilli during the period of cultivation is similar to the previous results: up to $48 \mathrm{~h}$ there is an exponential phase growth, from $48 \mathrm{~h}$ to $60 \mathrm{~h}$ of cultivation - a stationary phase growth, from $60 \mathrm{~h}$ to $72 \mathrm{~h}-\mathrm{a}$ death phase.

However, for all measurement points, co-culturing of lactobacilli with vitamin B5 showed an increase in viable cells already at $1 \%$ of the vitamin (for example, the result for the point $48 \mathrm{~h}$ was equal (4.65 \pm 0.11$\left.) 10^{9} \mathrm{CFU} / \mathrm{ml}\right)$ compared to the control (at $\left.48 \mathrm{~h}-(3.86 \pm 0.24) \cdot 10^{9} \mathrm{CFU} / \mathrm{ml}\right)$, and with the addition of $2.5 \%$ and $5 \%$, no statistically significant difference from $1 \%$ was observed (at the same point at $2.5 \%$ B5 cell count was $(4.65 \pm 0.13) \cdot 10^{9} \mathrm{CFU} / \mathrm{ml}$, at $5 \% \mathrm{~B} 5-$ $\left.(4.66 \pm 0.15) \cdot 10^{9} \mathrm{CFU} / \mathrm{ml}\right)$. Of course, vitamin B5 is a growth factor for lactobacilli, but glucose is the main nutritional component, so when it is deficient, even increasing the concentration of vitamins does not lead to increase in the number of cells. This may explain in this case the absence of a significant difference when increasing the amount of vitamin.

The results of a series of experiments with the addition of provitamin B5 D-panthenol at concentrations of $1 \%, 2.5 \%$ and $5 \%$ to the nutrient medium are presented in Fig. 3. The general tendency of accumulation of lactobacilli biomass with the addition of this active ingredient is similar to the previous one, so it was interesting to consider the dynamics of lactobacilli growth in the form of more obvious curves of lactobacilli growth (in all other series of experiments the curves were superimposed on each other, that prevented clarity).

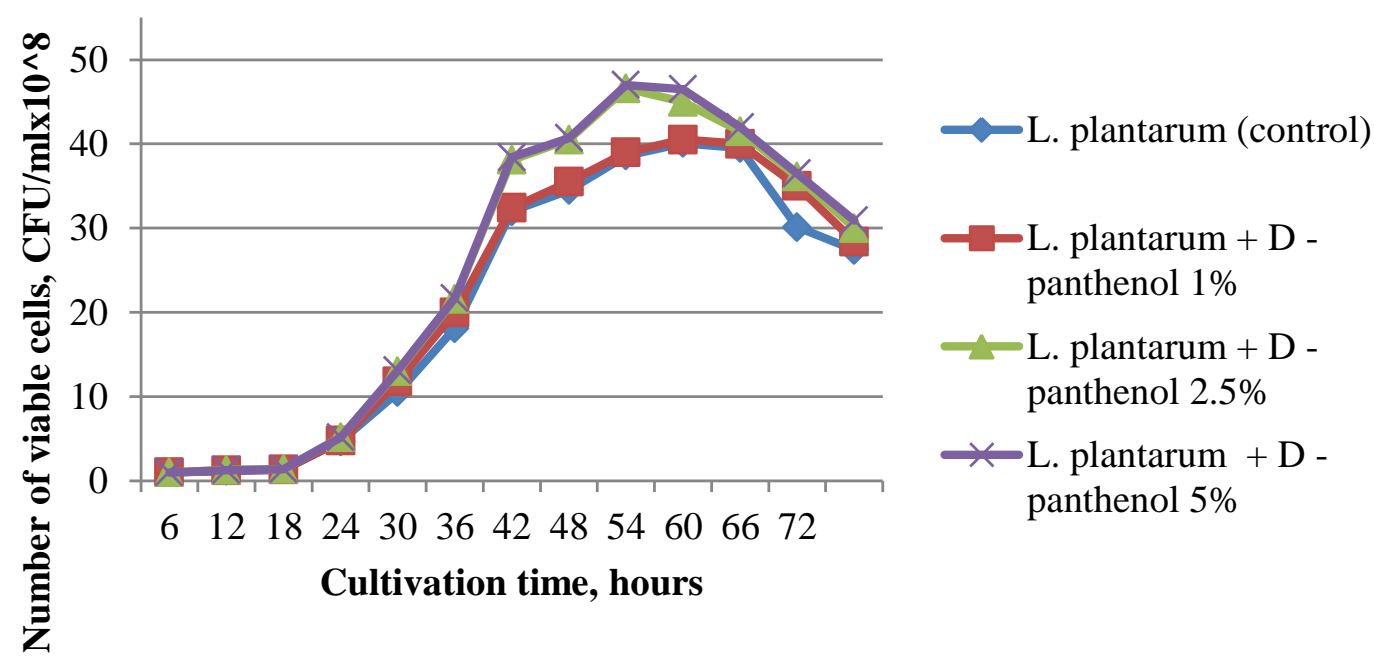

Fig. 3. Growth dynamics of L. plantarum B-2693 co-cultivated with D-panthenol 
In co-cultivation of lactobacilli with D-panthenol, there was a slight increase in viable cells with $1 \%$ provitamin (results at $48 \mathrm{~h}$ were equal to $\left.(3.90 \pm 0.12) \cdot 10^{9} \mathrm{CFU} / \mathrm{ml}\right)$ and a significant increase with $2.5 \%$ (results for the same point were $(4.66 \pm 0.13) \cdot 10^{9} \mathrm{CFU} / \mathrm{ml}$ ) and $5 \%$ (results for the same point were $\left.(4.70 \pm 0.26) \cdot 10^{9} \mathrm{CFU} / \mathrm{ml}\right)$, and between them were slight differences.

Cultivation of lactobacilli with methylcobalamin in concentrations of $0.5 \%, 0.75 \%$ and $1 \%$ (Fig. 4) showed a slight positive effect on the increase of lactobacilli biomass with increasing vitamin concentration in the nutrient medium. Thus, the growth of viable cells ended by $54 \mathrm{~h}$ : to control at this point the cell count was $(4.01 \pm 0.15) \cdot 10^{9} \mathrm{CFU} / \mathrm{ml}$, when cultured with $0.5 \%$ $\mathrm{B} 12-(4.10 \pm 0.21) \cdot 10^{9} \mathrm{CFU} / \mathrm{ml}$, with $0.75 \%$ $\mathrm{B} 12-(4.15 \pm 0.02) \cdot 10^{9} \mathrm{CFU} / \mathrm{ml}$, with $1 \%$ $\mathrm{B} 12-(4.05 \pm 0.15) \cdot 10^{9} \mathrm{CFU} / \mathrm{ml}$.

During cultivation with milk protein complex (CMP) in concentrations of $1 \%, 2.5 \%, 5 \%$ (Fig. 5), the increase in the number of lactobacilli cells is not signifi- cant. Nevertheless, unlike cases of cultivation with vitamins, the increase in growth rate did not stop at $54 \mathrm{~h}$ observation, and at $48 \mathrm{~h}$, and from $54 \mathrm{~h}$ the beginning of the accelerated death phase is traced, during which the equilibrium between the stationary phase and the rate of death of lactobacilli occurs. In addition, at this point the $\mathrm{pH}$ was much lower than for other cases (Table 1), which may be explained by the stimulation of milk fermentation of a complex of vitamins and amino acids with the formation of more lactic acid than in other cases.

Cultivation of lactobacilli with $\alpha$-lipoic acid (LA) at concentrations of $2 \%, 3.5 \%$ and $5 \%$ (Fig. 6) compared to control, has no significant effect on lactobacilli, which may be explained by the fact that lipoate plays a role of coenzyme in oxygen metabolism, especially in pyruvate dehydrogenase complex, irrelevant for the metabolism of lactobacilli.

In parallel for all series of experiments throughout the cycle of cultivation, determination of the acidity of the culture fluid was performed (Table 1).

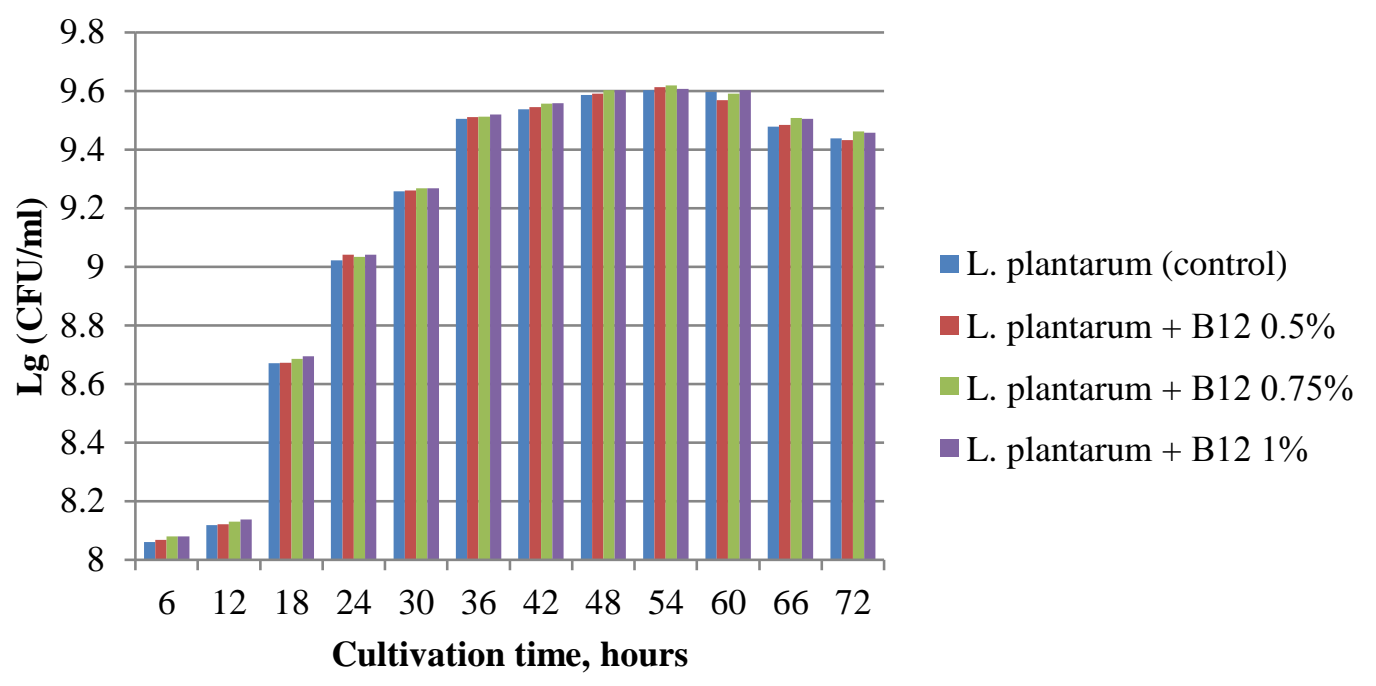

Fig. 4. Growth dynamics of L. plantarum B-2693 co-cultivated with methylcobalamin

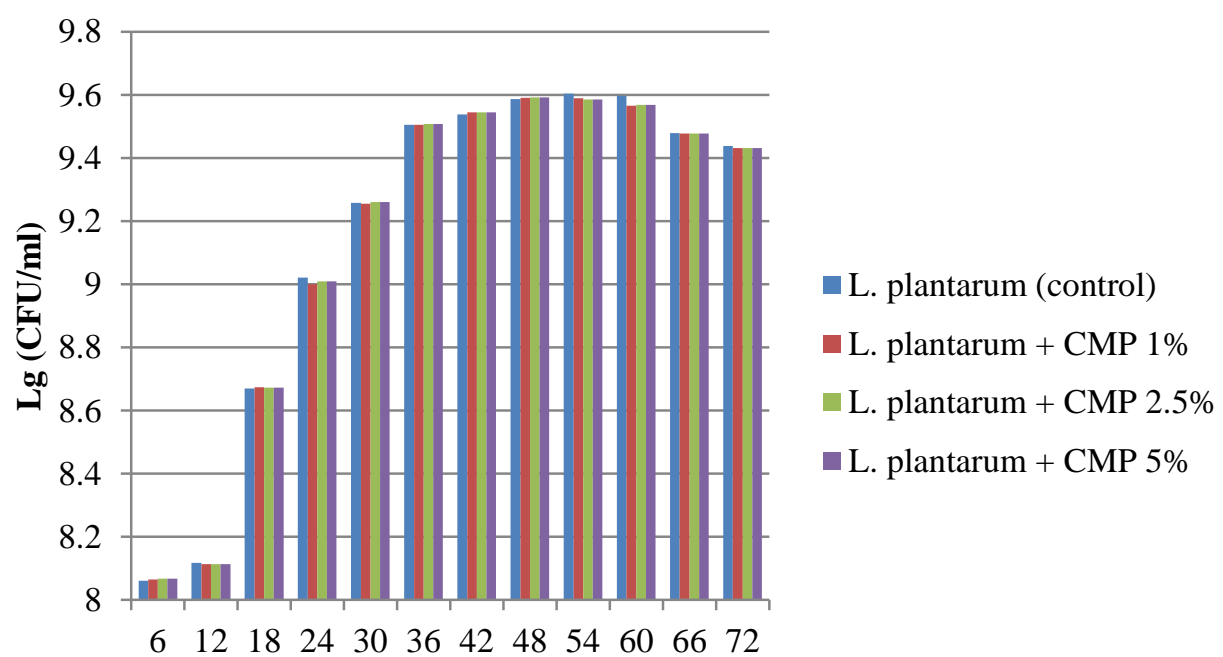

$\begin{array}{llllllllllll}6 & 12 & 18 & 24 & 30 & 36 & 42 & 48 & 54 & 60 & 66 & 72\end{array}$

Cultivation time, hours

Fig. 5. Growth dynamics of L. plantarum B-2693 co-cultivation with milk protein complex (CMP) 


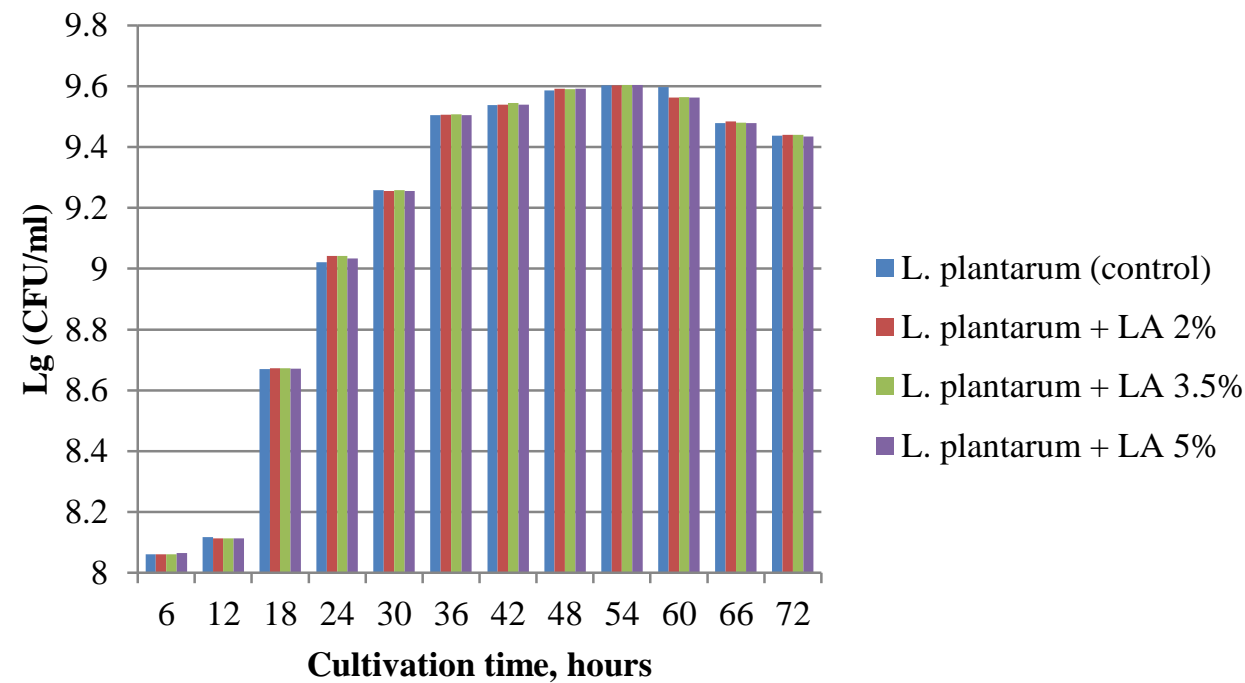

Fig. 6. Growth dynamics of L. plantarum B-2693 co-cultivation with $\alpha$-lipoic acid (LA)

Table 1

$\mathrm{pH}$ values in the culture fluid of L. plantarum B-2693 during cultivation with active ingredients

\begin{tabular}{|c|c|c|c|c|c|c|c|}
\hline \multirow{2}{*}{$\begin{array}{l}\text { Culti- } \\
\text { vation } \\
\text { time }\end{array}$} & \multicolumn{7}{|c|}{$\mathrm{pH} *$} \\
\hline & Control & $0.1 \%$ B6 & $1 \%$ B5 & $\begin{array}{l}2.5 \% \mathrm{D}- \\
\text { panthenol }\end{array}$ & $1 \% \mathrm{CMP}$ & $0.5 \%$ B12 & $2 \%$ LA \\
\hline 6 & 6.5 & 6.5 & 6.5 & 6.4 & 6.4 & 6.5 & 6.5 \\
\hline 12 & 6.4 & 6.3 & 6.2 & 6.2 & 6.2 & 6.3 & 6.3 \\
\hline 18 & 6.2 & 6.2 & 6.2 & 6.1 & 6.1 & 6.2 & 6.1 \\
\hline 24 & 5.3 & 5.2 & 5.1 & 5.0 & 5.0 & 5.2 & 5.2 \\
\hline 30 & 4.9 & 4.8 & 4.6 & 4.6 & 4.7 & 4.9 & 4.8 \\
\hline 36 & 4.8 & 4.8 & 4.5 & 4.4 & 4.5 & 4.8 & 4.7 \\
\hline 42 & 4.7 & 4.7 & 4.4 & 4.3 & 4.4 & 4.7 & 4.6 \\
\hline 48 & 4.5 & 4.5 & 4.2 & 4.2 & 4.0 & 4.5 & 4.4 \\
\hline 54 & 4.3 & 4.3 & 4.2 & 4.1 & 4.0 & 4.3 & 4.3 \\
\hline 60 & 4.2 & 4.2 & 4.1 & 4.1 & 3.9 & 4.2 & 4.2 \\
\hline 66 & 4.0 & 4.0 & 4.1 & 4.0 & 3.9 & 4.1 & 4.0 \\
\hline 72 & 4.0 & 4.0 & 4.0 & 3.9 & 3.9 & 4.0 & 4.0 \\
\hline
\end{tabular}

Note: *-data for cultivation with active ingredients at concentrations proposed as promising in the dosage form

According to the results of Tab. 1, we observe a general trend of decreasing $\mathrm{pH}$ from $6.4-6.5$ to $3.9-4.0$ during $72 \mathrm{~h}$, which is due to the utilization of glucose in the process of cultivation of lactobacilli, which is a part of the nutrient medium, and the formation of metabolic products in the first turn lactic acid. This will have an overall positive effect on the dynamics of dermatological diseases not only due to the need to reduce $\mathrm{pH}$ of the skin, but also due to the antimicrobial action of substances formed during the metabolism of lactobacilli.

\section{Discussion of research results}

It is known that the growth and metabolic functions of lactobacilli are related to the so-called growth factors. For lactobacilli growth factors are vitamins, especially group $\mathrm{B}$, and similar to vitamins substances [12]. That is why, choosing the optimal conditions for lactobacilli has one of the requirements - sufficient content of vitamins in the nutrient medium, but similar studies use multi-constituent components of the nutrient medium that are a mixture of undetermined substances rather than individual substances [16, 17].

The results of our experiments made it possible to distinguish the following general trends of the bacterial population growth curve for the series of experiments with L. plantarum B-2693 combined with growth factors - vitamins and vitamin-like substances at selected concentrations. During $48 \mathrm{~h}$ of cultivation, there is a significant increase in viable lactobacilli cells, both in control and with the addition of vitamins at selected concentrations (exponential bacterial growth phase). From $48 \mathrm{~h}$ to $60 \mathrm{~h}$ of cultivation there is a decrease in the rate of increase of viable cells both in control and with the addition of vitamins at selected concentrations, the number of cells remains almost constant (stationary phase of bacterial growth - lack of nutrients for growth as a result of glucose utilization and use other nutrients and growth factors). After $60 \mathrm{~h}$ there is a decrease in the number of viable cells (logarithmic dying phase).

During cultivation, acidification of the nutrient medium $\mathrm{pH}$ from $6.4-6.5$ to $3.9-4.0$ was observed as a result of the formation of lactic acid from carbohydrates (up to $85 \%$ or more) and other terminal metabolites; that is, the addition of growth factors slightly increases the biochemical potential of microorganisms, as evidenced by the increase in biomass and acid potential.

Although there is no significant difference between one series of experiments with different vitamins, it can be noted that the largest increase in viable cells 
was observed when grown with vitamin B5 (among selected concentrations $-1 \%)$ and provitamin B5 (2.5\%).

Study limitations. Study reflects only the possibility of joint using of selected substances with lactobacilli in concentrations, the choice of which is based on their use in the composition of dermatological preparations, and not the stimulation of lactobacilli during their cultivation for other purposes.

Prospects for further research. According to the results of the studies, it is planned to carry out further researches to study the technological and pharmacological properties of active components for selecting the most optimal for the composition of the complex dermatological therapeutic and preventive medicine with probiotic.

\section{Conclusions}

Thus, according to the defining of microbiological parameters it is possible to state the prospect of using selected prebiotic components with lactobacilli in the composition of one dosage form that is being developed. Despite the pronounced synergism of action for the vitamin B5 and Dpanthenol series of experiments, all other components are also promising due to the lack of negative effects on lactobacilli and a number of positive effects on human skin.

From the selected concentrations studied, from the economic point of view it is possible to stay at the minimum: for vitamins B $6-0.1 \%, \mathrm{~B} 5-1 \%, \mathrm{~B} 12-0.5 \%$, for D-panthenol $-2.5 \%$, for milk proteins complex $-1 \%$, for $\alpha$-lipoic acid $-2 \%$. Minimum concentration is possible due to the planning of the use of several prebiotic components, but the final selection of the active components in the composition of the dermatological medicine with a probiotic is possible in the following defining of pharmacological and technological parameters.

\section{Conflict of interests}

There are no conflicts of interest regarding this study.

\section{References}

1. Stepanenko, V. I. (Ed.) (2012). Dermatologiya i venerologiya. Kyiv: KIM, 848.

2. Turnbaugh, P. J., Ley, R. E., Hamady, M., Fraser-Liggett, C. M., Knight, R., Gordon, J. I. (2007). The Human Microbiome Project. Nature, 449 (7164), 804-810. doi: http://doi.org/10.1038/nature06244

3. Araviiskaia, E. P., Sokolovskii, E. V. (2016). Microbiome: a new era in normal and pathological changes skin studies. Vestnik dermatologii i venerologii, 3, 102-109.

4. Grice, E. A., Kong, H. H., Conlan, S., Deming, C. B., Davis, J. et. al. (2009). Topographical and Temporal Diversity of the Human Skin Microbiome. Science, 324 (5931), 1190-1192. doi: http://doi.org/10.1126/science.1171700

5. Cogen, A. L., Nizet, V., Gallo, R. L. (2008). Skin microbiota: a source of disease or defence? British Journal of Dermatology, 158 (3), 442-455. doi: http://doi.org/10.1111/j.1365-2133.2008.08437.x

6. Structure, function and diversity of the healthy human microbiome (2012). Nature, 486 (7402), 207-214. doi: http://doi.org/10.1038/nature11234

7. Yatsunenko, T., Rey, F. E., Manary, M. J., Trehan, I., Dominguez-Bello, M. G., Contreras, M. et. al. (2012). Human gut microbiome viewed across age and geography. Nature, 486 (7402), 222-227. doi: http://doi.org/10.1038/nature11053

8. Nakatsuji, T., Chiang, H.-I., Jiang, S. B., Nagarajan, H., Zengler, K., Gallo, R. L. (2013). The microbiome extends to subepidermal compartments of normal skin. Nature Communications, 4 (1). doi: http://doi.org/10.1038/ncomms2441

9. Muizzuddin, N., Maher, W., Sullivan, M. (2012). Physiological effect of a probiotic on skin. Cosmet Sci, 63, 385-395.

10. Chicherin, I. Y., Pogorelskiy, I. P., Lundovskikh, I. A., Malov, A. A., Shabalina, M. R., Darmov, I. V. (2013). Dynamics of the Content of Lactobacilli, Microbial Metabolites and Antimicrobial Activity of Growing Culture of Lactobacillus Plantarum 8PA3. Journal Infectology, 5 (3), 50-55.

11. Yarullina, D. R., Fahrullin, R. F. (2014). Bakterii roda Lactobacillus: obshaya harakteristika i metody raboty s nimi. Kazan: Kazanskii universitet, 51.

12. Mesquita, A. R. C. de, Silveira, L. P. da M., Cruz Filho, I. J. D., Lima, V. F. de, Silveira Filho, V. D. M., Araujo, A. A et. al. (2017). Metabolism and physiology of Lactobacilli: a review. Journal of Environmental Analysis and Progress, 2 (2), $125-136$. doi: http://doi.org/10.24221/jeap.2.2.2017.1202.115-124

13. Bespomestnyh, K. V. (2014). Izuchenie vliyaniya sostava pitatelnoj sredy na izmenenie biohimicheskih i morfologicheskih svoistv shtammov laktobacill. Sovremennye problemy nauki i obrazovaniya, 6. Available at: https://www.scienceeducation.ru/ru/article/view?id=16600

14. Kaliuzhnaia, O. S., Strelnikov, L. S., Strilets, O. P., Kabachniy, G. I. (2009). Rozrobka skladu i tehnologiyi supozitoriyiv dlya profilaktiki ta likuvannya vaginalnih disbioziv. Zaporozhskii medytsynskyi zhurnal, 11 (3), 86-89.

15. Fadeeva, I. V. (2004). Razrabotka kompleksnogo probioticheskogo preparata na osnove laktobakterii. Perm, 24.

16. Akulevich, O. V., Oryabinska, L. B., Dugan, O. M. (2013). Kinetika rostu molochnokislih bakterii rodu Lactobacillus na zhivilnih seredovishah z riznomanitnimi dzerelami vuglecevogo I azotnogo. Naukovi visti NTUU «KPI», 3, 7-11.

17. Hizhnyak, O. S. (2016). Rozrobka skaldu ta biotechnologii otrimannya komplesnogo probiotichnogo preparatu. Kharkiv, 204.

Received date 18.03 .2020

Accepted date 08.04.2020

Published date 30.04.2020

Alina Soloviova, Postgraduate Student, Assistant, Department of Biotechnology, National University of Pharmacy, Pushkinska str., 53, Kharkiv, Ukraine, 61002

E-mail: soloviova.alina@gmail.com

Olha Kaliuzhnaia, PhD, Associate Professor, Department of Biotechnology, National University of Pharmacy Pushkinska str., 53, Kharkiv, Ukraine, 61002

E-mail: kalyuzhnayao.s@gmail.com

Leonid Strelnikov, Doctor of Pharmaceutical Sciences, Professor, Department of Biotechnology, National University of Pharmacy, Pushkinska str., 53, Kharkiv, Ukraine, 61002

E-mail: biotech.leonid@gmail.com 